\title{
Zaparoan negation revisited ${ }^{1}$
}

Negação em Záparo revisitada

\author{
Johan van der Auwera ${ }^{2}$ \\ Olga Krasnoukhova ${ }^{3}$
}

DOI 10.26512/rbla.v11i02.27300

Recebido em setembro/2019 e aceito em outubro/2019.

\begin{abstract}
The paper revisits negation in the Zaparoan languages Arabela, Iquito and Záparo. For Iquito, which exhibits single, double as well as triple negation, we adopt a Jespersen Cycle perspective and for Záparo and Arabela it is the Negative Existential Cycle which proves enlightening. We speculate that both in Iquito and Záparo there is a diachronic link between the formal expression of negation and the concept of 'leaving'. We address the internal subclassification of the Zaparoan languages, showing that, at least for the structural feature of negation, the position of Arabela is closer to Záparo than to Iquito.
\end{abstract}

Key words: Zaparoan. Standard negation. Existential negation. Prohibitives. Jespersen Cycle. Negative Existential Cycle.

\section{Resumo}

O artigo revisita a negação nas línguas Záparo Arabela, Iquito e Záparo. Para Iquito, que exibe negação única, dupla e tripla, adotamos a perspectiva do Ciclo de Jespersen e, para Záparo e Arabela, é o Ciclo Existencial Negativo que se mostra esclarecedor. Hipotetizamos que tanto em Iquito quanto em Záparo existe um vínculo diacrônico entre a expressão

1 This paper emanates from a larger project on the typology of negation in the indigenous languages of South America, supported by the Research Foundation Flanders. We are grateful to Joshua Birchall (Museu Paraense Emilio Goeldi, Belém), Cynthia Hansen (Grinnell College, Iowa), and Lev Michael (UC Berkeley) for comments on earlier versions of the paper. We follow the orthography and the glossing of the sources as closely as possible. On Iquito orthography see http://tipishca.blogspot.com/2014/08/normalizaciondel-alfabeto-de-la-lengua.html.

2 Professor Emérito de Linguística Geral e de Inglês, Universidade de Antwerp, Departamento de Linguística, Bélgica.johan.vanderauwera@uantwerpen.be.

3 Pós-doutoranda, Universitdade de Antwerp, Departamento de Linguística, Bélgica. olga. krasnoukhova@uantwerpen.be 
formal da negação e o conceito de 'partir'. Abordamos a subclassificação interna das línguas zaparoanas, mostrando que, pelo menos quanto ao aspecto estrutural da negação, a posição de Arabela está mais próxima de Záparo do que de Iquito.

Palavras-chave: Záparo. Negação padrão. Negação existencial. Proibitivos. Ciclo de Jespersen. Ciclo Existencial Negativo.

\section{Introduction}

The Zaparoan languages are spoken in Peru and Ecuador. They constitute a small family, with Hammarström et al. (2019) (Glottolog), for instance, listing six languages, all of them highly threatened. This paper focusses on three languages, viz. Arabela (glottocode arab1268, Peru), Iquito (glottocode iqui2018, Peru) and Záparo (glottocode zapa1253, Ecuador), probably the only ones that still have native speakers (Wise 1999: 308, 2005: 51-52; Crevels 2012: 211; Hansen 2018: 131; Beier \& Michael 2018: 406). Iquito has the best descriptions, especially in the form of two doctoral dissertations at the University of Texas at Austin (Lai 2009 and Hansen 2011) and most relevant, given that this paper is about negation, is a specialist study of subordinate and interrogative negation (Hansen 2018). Our paper also refers to the older description of Iquito by Eastman \& Eastman (1963). For Arabela, our two sources are older too, viz. Rich $(1975,1999)$ and we also have recourse to Peeke (1954), which deals with the (very nearly) extinct close relative Andoa. Záparo has seen three recent studies, Moya $(2007,2009)$ and Beier et al (2014) and two older ones (Peeke 1962, 1991).

Zaparoan negation has some intriguing properties. This paper aims to help explain these properties. It strongly relies on Hansen's (2018) work on Iquito negation, but it differs in four respects. First, for Iquito Hansen focusses on how subordinate and interrogative negation strategies work, as partially different from standard negation. Our focus is on how some of the strategies relate to one another in terms of the number of exponents. Second, we dare to put forward a hypothesis on possible diachronies, grounded on differences between the various language-specific accounts and on what we know about negation typologically. Third, we also bring in Arabela and Záparo. Fourth, we show how the negation facts relate to the internal classification of Zaparoan.

\section{Iquito negation}

In the world's languages clausal negation usually has just one exponent, double negation is not rare, triple exponence is rarer, and quadruple and quintuple negation even more so (van der Auwera \& Krasnoukhova (Forthc.)). This is best studied for declarative main clauses (cf. Dryer 2013; Vossen 2016). Iquito has single, double as well as triple negation. There are furthermore two subtypes of double as well as of single exponence, and all of the by now five strategies 
except one are restricted to specific clause types, with the main (interacting) parameters being \pm subordinate, \pm yes/no interrogative, and \pm irrealis. The combination of triple exponence, two subtypes of double exponence and two subtypes of single exponence, and the complicated contextual parameters probably makes for a rarissimum. (1) to (3) illustrate the variable exponence of negation in non-imperative main clauses - we turn to imperative ones later. Specifically, (1) shows a single exponence, which can be either with a preverbal $k a a$ particle or a suffixal -ji. (2) illustrates double marking: kaa combines with $-j i$ and both orders are possible. (3) shows triple exponence: it has kaa both before and after $-j i$.

(1) Iquito (Hansen 2018: 137, 143)
a.
Kaa nu=jikatii- $\varnothing$
NEG 3GEN=leave.IMPF-NPST
'He is not leaving.'
b. Kániika nft- ’ji-ki-Ø iyákumata?
who run-NEG-PRF-NPST quickly
'Who didn't run quickly?'

(2) Iquito (Hansen 2018: 149, 151)
a. Kániikakaa áni-'ji-aárii-Ø?
who NEG1 arrive-NEG2.INCP-NPST
'Who won't be arriving?'
b Kániika amátana nłtt- ’ji-rı-Ø
who quickly run-NEG1-MMT.PRF-NPST NEG2
'Who will not run quickly?'

(3) Iquito (Hansen 2018: 121)

$\begin{array}{lllll}\text { Kániika } & \text { kaa } & \text { jikata-'ji-rii- } \varnothing & k a a & \text { nu-náana? } \\ \text { who NEG1 } & \text { remove-NEG2-PRF-NPST } & \text { NEG3 } & \text { 3GEN.POSS=wood } \\ \text { 'Who will not remove his/her wood?' } & & \end{array}$

Let us focus first on double negation with its two exponents, the particle $k a a$ and the suffix -ji-. Givón's one-liner (1971: 413) that "today's syntax is tomorrow's morphology" makes it plausible that the suffix is older than the particle. It is not only bound, it occurs close to the verbal root and is followed by other verbal morphology. This does not mean, however, that $-j i$ - is older than $k a a$ in its negator function. We will see below that prohibitive negation can be double too, also with a particle and a suffix. The particle is again kaa, but the suffix is -kuma. A Givón inspired hypothesis would have -kuma as the older

4 The number following the NEG glosses, i.e., the difference between NEG1, NEG2 and NEG3, reflects the position in the linear order. 
formative, but it is one of potentiality, not of negation, to the extent even that grammarians are reluctant to consider it as a negator (see below). However, in the case of Iquito, -ji- is likely to be an older negator than kaa and not just an older formative. Hansen (2018: 157) points to Peeke's (1954: 175) description of a $-u-/-y u$ - verbal negator in Andoa, which could be related, and together with Lev Michael (personal communcation to Cynthia Hansen), she thinks that one could therefore reconstruct it to a proto-Zaparoan negator.

All of this is not to say that we can't say anything about an earlier nonnegative meaning of the -ji- negator. Hansen (2018: 142) mentions that Iquito has a $j i$ postposition meaning 'from, out of'. She basically considers the similarity between the suffix and the postposition to be a case of homonymy. Synchronically, this cannot be questioned. She does not go into the diachrony, apart from saying that '[d]irectionals are not generally considered to be a historical source for negative marking' and pointing to literature suggesting an indirect link between 'movement from' and partitive case and between partitive case and negators (Hansen 2018: 142). However, already Heine \& Kuteva (2002: 192) (now also Kuteva et al. 2019: 255-256), referred to in Miestamo (2005: 223), speak about a direct link between the semantics of 'movement from' and negation. In Dewoin (glottocode dewo1238, Liberia) se means 'leave' but it also serves as a negator.

(4) Dewoin (Heine \& Kuteva 2002: 142, referring to Marchese 1986: 182)

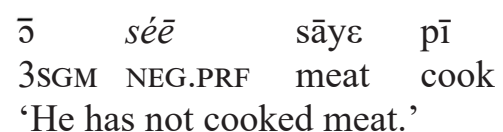

For an Amazonian illustration, we can bring in Nadëb (glottocode nade1244, Brasil) and Wari' (glottocode wari1268, Brazil). In Nadëb, the prohibitive negator manih might derive from the verb a-nith 'leave' (Weir 1984: 256257). In Wari', the postverbal modifier mao 'negative' (terminology of Everett \& Kern 1997: 171) is hypothesized to originate in the verb mao 'go/leave' (Hober 2019). The verb mao 'go/leave' is commonly used as part of a serial verb construction and can occur at the end of a serialization (Joshua Birchall, p.c.). In Wari' it is common for verbs in the final position of a serialization to be reanalysed as a type of modifier (idem, see Birchall 2014), in this case with the negator function. These data suggest that in Iquito there may be a non-trivial link between the andative postposition $-j i$ and the negator - $j i$ - particularly, as Iquito's own 'leave' and 'remove' verbs jikatii and jikata (see (1a) and (3)) are formally similar, too.

How direct the link is between the postposition $j i$ and the negator -ji- must be left open. Lev Michael (p.c.) informs us that on the basis of phonological and morphological evidence, a direct link between the postposition and the negator 
would be 'extremely' unlikely and stresses that our language-internal evidence so far only consists of two short forms with two currently different meanings. There is, however, family-internal evidence to support a link between a 'leave' verb and a negator. Záparo has a preverbal standard negator taykwa (Peeke 1962: 130; Moya 2007: 174, 198). The -kwa part is formally close to the Iquito negative particle $\mathrm{kaa}$ and could thus be related. Crucially, Záparo has also an andative suffix - $k w a$ meaning 'leaving, going away from' (Beier et al 2014: 54). And there is also a verb with 'go/leave, travel' semantics ('ir', 'viajar' in the source material) in the form of ikwanu (Beier et al 2014: 37), which contains the root ikwa 'go', listed as a Záparoan etymology in de Carvalho (2013: 112). So Záparo allows for an andative conjecture, too. Of course, once again, we have no direct evidence that the $-k w a$ in taykwa is related to the suffix as well as the verb, and we don't know what tay- is. The sceptic would furthermore say that the likelihood of one conjecture is not strengthened by bringing in another one. Still, rejecting the andative conjecture out of hand is not right either. We know that negation may come from 'leave' semantics and we here have two languages in which exponents of negation and 'leaving' are similar. Interestingly, the languages, i.e., Iquito and Záparo, are closely related, but the formatives, i.e., $-j i$ and $-k w a$ are not. If the andative conjectures are supported, this similarity in pattern, but not matter, could be a result of a contact-induced grammaticalization process discussed in Heine \& Kuteva (2003: 533) and Gast $\&$ van der Auwera (2012: 389). And while these authors discuss cases involving unrelated languages, it is no less possible for sister-languages, as these "continue to reside side by side, allowing regular contact and transference among their speakers" (Epps et al. 2013: 211-212). Let us now return to the syntactic pattern of double negation in Iquito. When two negators cooccur in order to express just one semantic clausal negation, this invites a Jespersen Cycle analysis. Even though there is more than one definition of a Jespersen Cycles (van der Auwera 2009, van der Auwera et al Forthc.), there is agreement that a doubling pattern develops out of a pattern with just one negator. In the classical Jespersen Cycle, as in the textbook case of French, the doubling pattern, which involves a reinterpretation of a noun pas 'step' as a negator, gets replaced by a pattern with just one negator, just like in the pre-doubling stage, but the negators in the first and third stage are different.

(5) French

ne $\mathrm{V} \rightarrow$ ne $\mathrm{V}$ pas $\rightarrow \quad \mathrm{V}$ pas

The alternative to a return to single exponence is a continuation to triple exponence. (6) is an example from the mid-twentieth century Brabantic Belgian Dutch dialect.

(6) Brabantic Belgian Dutch (van der Auwera 2010: 84-85, referring to 
Pauwels 1958: 454)

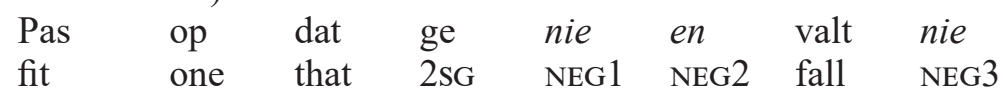

'Take care that you don't fall.'

In Dutch en is the oldest negator, which was strengthened by nie - or niet in a way similar to the way French ne got strengthened. But there is a difference, too, for in Dutch the doubling stage allows both the en ... nie and nie ... en order, the latter being the one in finite subordinate clauses. In standard Dutch en then disappeared, but in the Flemish and Brabantic dialects it stayed on, though in Brabantic only in finite subordinate clauses, the assumption being that this clause type is better at keeping archaisms (see Salaberri 2017: 4-8 for a discussion and references). In Brabantic the Jespersen Cycle took a new round copying nie in a clause-final position, usually yielding doubling, but in the case of Brabantic finite subordinate clauses, it yielded tripling (van der Auwera 2010: 83-84). The latter structure is both archaic (retention of en) and innovative (copying nie).

(7) Brabantic Belgian Dutch

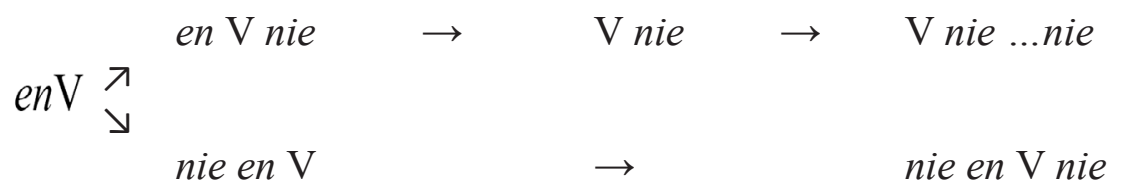

A Jespersen Cycle looks promising for Iquito, for as we have seen in (1) to (3), the language does not only have double negation, but also single and triple negation. There are more similarities. First, like in Dutch, the single exponence pattern is the most frequent and contextually least restrained pattern. Second, like in Brabantic, the doubling pattern allows two orders, i.e., V-ji kaa and kaa $\mathrm{V}-j i$. Third, like in Brabantic, one of the double exponence orders is restricted to what is arguably an archaic context: whereas V-ji kaa occurs in both realis and irrealis contexts, the $k a a-j i$ order only occurs in irrealis contexts, and the latter have been argued by Hansen (2011: 224-231) to derive from subordinate clauses. Fourth, the tripling order is restricted to irrealis, with old subordinate clause order, but it combines retention and innovation, and the innovation happens with a postverbal copy, not unlike what is hypothesized for Brabantic. Fifth, not unlike in Brabantic, in which single exponence is no longer attested at least not with a negative meaning ${ }^{5}$ - in Iquito the single exponence pattern is of limited grammaticality. ${ }^{6}(8)$ sketches the commonalities. The most restricted

5 In some dialects it survived as a marker of subordination, as this was the context in which it survived longest (van der Auwera 2009: 59-60, Van de Velde \& Norde 2016: 12-13).

6 The single exponence pattern never occurred in Hansen's (2011) text corpus, the informant with the 'strongest grammaticality judgments' rejected single exponence, three others used 
patterns are enclosed with the dashed line. Dutch single en, which is not used for negation anymore, is put between brackets.

$$
\begin{array}{llll}
\text { old single } & \text { double } & \text { new single } & \text { triple } \\
\text { exponence } & \text { exponence } & \text { exponence } & \text { exponence }
\end{array}
$$

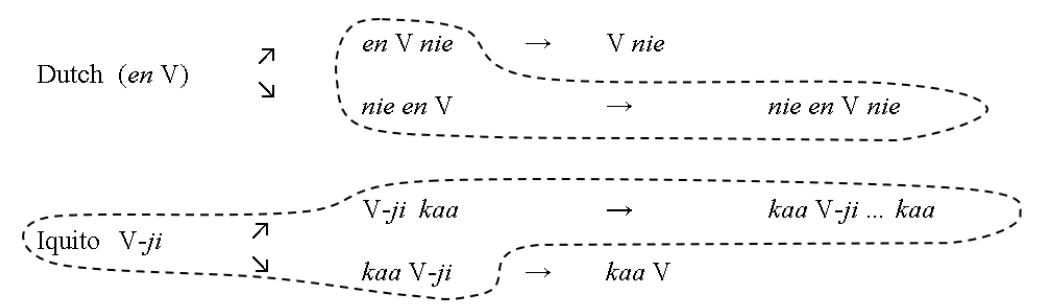

Of course, there are differences, too. Most importantly, in the old single exponence pattern the Dutch negator is preverbal, but postverbal in Iquito and, relatedly, the new negator is postverbal in Dutch, but preverbal in Iquito. The direction of the Jespersen Cycle in Iquito is thus not the 'classical' left-to-right one, but that it is only because the classical directionality is based on French and English. There is nothing extraordinary about non-classically directed Jespersen Cycles anymore: it has been posited for other languages (van der Auwera \& Vossen 2016; Vossen 2016 passim; Krasnoukhova \& van der Auwera 2019: 454). Furthermore, the right-to-left direction is in line with another principle owed to Jespersen (1917: 5), i.e., the 'Negative First' principle - a term coined by Horn (1989: 293) - basically saying that everything else being equal, it is important to express the negation early in the sentence. Interestingly, deriving $k a a \mathrm{~V}-j i k a a$ from V-ji kaa is also in conformity with the principle: what kaa $\mathrm{V}-j i$ kaa does as compared to $\mathrm{V}-j i k a a$ is to add an early negator.

Of course, it is not to be ruled out that kaa V-ji kaa derives from kaa $\mathrm{V}-j i$. This is not unreasonable: tripling would add a postverbal $k a a$, just like $\mathrm{V}-j i$ $k a a$ doubling adds a postverbal kaa to V-ji. kaa V-ji kaa and kaa V-ji share an irrealis feature - at least synchronically - and they are the only ones that only allow irrealis readings - synchronically again. Also, in a totally different domain, Iquito allows doubling of one and the same element, viz. a demonstrative, both in the preverbal and a postverbal position, somewhat like the way negation tripling involves doubling of an identical element, viz. kaa in preverbal and postverbal positions (Hansen 2011: 71, 163-168).

(9) Iquito (Hansen 2011: 163)

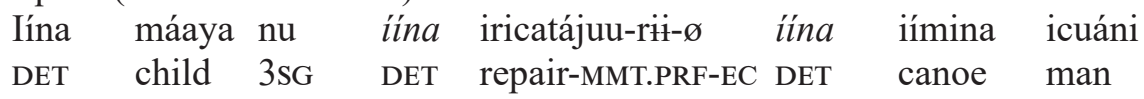

it only in irrealis interrogatives, and the fourth one both in realis interrogatives and in one type of irrealis interrogatives. 
'The child will repair this canoe of this man.'

There is thus a similarity and this could ease a change from kaa V-ji to kaa V-ji kaa. The similarity is superficial though, as Hansen (2011: 166-167) also remarks, and she convincingly explains determiner doubling as a reinterpretation of coreferential pronouns.

In any case the scenario sketched in (8) must remain very tentative. Yet it remains highly plausible that both the kaa single exponence pattern and tripling result from doubling. That the -ji- single exponence is the older pattern is plausible too, but that does not mean that current speakers take the single -ji- negator as a relic. Speakers are not linguists: they may not have intuitions about the meaning of $-j i$ - other than that it is a concomitant of the negator kaa: it could be seen as being necessary for negation without itself being negative. However, precisely because it is a noticeable concomitant of the negator kaa, the latter could 'contaminate' it with negative meaning - and we will see, when we come to prohibitives, that there is independent Iquito evidence for this kind of process. Hansen (2018: 143) mentions both analyses of - $j i$ too, i.e., the view that it is an old, relic negator and the view that it is a new one, owing its negative force to its co-occurrence with the kaa negator. The point we are making here is that these analyses do not exclude each other. The first one is about the change from a protoform and the second is about ongoing or recent change.

Let us now turn to Iquito prohibitives. Like main clause declaratives, prohibitives do not use the $-j i$ - negator but only the kaa negator. ${ }^{7}$

(10) Iquito (Lai 2009: 263)

$c a=$ quina $=$ cuhasi- $\varnothing$-cuma saaca

$\mathrm{NEG}=2 \mathrm{PL}=$ talk $=$ GNR.PFV-POT $\quad$ thing

'You all, don't say anything.'

In this construction the verb uses a potentiality suffix, indicating 'a weak prediction in the distant future' (Lai 2009: 222). Example (10) shows a $2^{\text {nd }}$ plural prohibitive. When the prohibitive is addressed to a $2^{\text {nd }}$ singular addressee, Lai (2009: 60) claims that kaa - together with the cliticized subject pronoun - is optional.

(11) Iquito (Lai 2009: 60)

$\begin{array}{ll}(\mathrm{Ca} a=\text { quia }) & \text { iicua-Cuma } \\ \mathrm{NEG}=2 \mathrm{SG} & \text { go-POT }\end{array}$

'Don't leave/go!'

7 Lai (2009) spells kaa as caa. In the examples we will respect the orthography of the source, as announced in note 1 , but in the text we uniformly use the spelling kaa. Mutatis mutandis, we do the same for the spelling variation with kuma (Eastman \& Eastman 1963) vs. cuma (Lai 2009). 
One could expect that when kuma expresses prohibition all but itself, it is not a potentiality marker anymore, but, to wit, a prohibitive marker, but Lai (2009) does not go that far.

The earlier description by Eastman \& Eastman (1963: 165) is both different and similar in an interesting way. They agree that kuma is a suffix of potentiality in a distant future - in their words 'far-distant or never-to-come future'. But, according to Eastman \& Eastman, the prohibitive only uses the kuma suffix, i.e., there is no optional kaa negator. Thus Eastman \& Eastman (1963) would have an even stronger reason than Lai (2009) to analyse the kuma suffix of the prohibitive pattern to be the exponent of prohibition, but they don't do that either. Be that as it may, it is clear that Iquito prohibitives can do without kaa.

How do we account for this? There are three possible hypotheses. The first one is implicit in the account of Eastman \& Eastman (1963: 165). The kuma only version of (11) would invoke the hearer to leave in so distant a future that it makes no sense to leave at or closely following the moment of speaking. This is not implausible, but assuming Lai (2009) to be right that caa can or has to be added, Eastman \& Eastman (1963) would have to consider this as a further development, pushing prohibitives into a general template requiring kaa. But it is puzzling to see that this later stage would have progressed furthest in the $2^{\text {nd }}$ plural pattern, which is cross-linguistically less typical and, we assume, less frequent in the imperative than the $2^{\text {nd }}$ singular (van der Auwera, Dobrushina \& Goussev 2003). A second account takes us to Pakendorf \& Schalley (2007). They have shown that a potential marker can acquire a preventive meaning, which can turn into a prohibitive meaning. The potential 'You might fall' turns into a preventive 'Be careful not to fall' and then to a prohibitive 'Don't fall'. Here too, we have to assume a further stage in which the negator-free prohibitive adjusts to the general format of pairing negative meaning with $k a a$ or $-j i$.

$\begin{array}{lllll}\text { V-kuma } & > & \text { V-kuma } \\ \text { V-POT } & \text { V-PREV } & \text { V-kuma } & \text { V-PROH }\end{array} \rightarrow \quad \begin{aligned} & \text { kaa V-kuma } \\ & \text { NEG V-PROH }\end{aligned}$

It is true that the cases studied by Pakendorf \& Schalley (2007) do not document any language introducing a clausal negator to a construction that is already prohibitive. But that does not mean that it does not exist. However, this account has the same problem as that implicit in Eastman \& Eastman (1963). In the second account the most progressive structure is not found in the $2^{\text {nd }}$ singular. This is unlikely: the second singular prohibitive is bound to show the change first. And there is another problem: with a warning, the second stage of the second scenario, one is more likely to warn somebody about the immediate future. The meaning of kuma, however, relates to a distant future.

There is a third account, one that harks back at the Jespersen contamination hypothesis offered for the single -ji- pattern: kaa imbued kuma with negative 
meaning to the extent that kuma can now express prohibition by itself. In this approach we should not hesitate to gloss the suffix kuma alone as prohibitive, just like nobody hesitates glossing French pas in (5) as negative, even though it once meant and can still mean 'step'.
(13) kaa .... V-kuma >
NEG V-POT
kaa ... V-kuma $>$
NEG V-PROH
V-kuma
V-PROH

For completeness's sake, and because it makes a nice contrast with what we see in Záparo and Arabela, we can mention that existential negation is expressed with a dedicated marker ajapaqui (Lai 2009: 59; Hansen 2018: 141).

(14) Iquito (Lai 2009: 59)

Ajapaqui paapaaja (tíira).

NEG.EXI fish there

'There is no fish (there).'

To conclude, despite a good amount of unclarity, for Iquito a Jespersen Cycle scenario makes sense, both for the -ji- and kaa makers, both in their single exponence pattern and in combination with each other and with a former potential marker kuma.

\section{Záparo negation}

According to Peeke (1962: 130-131), discussed this way also by Adelaar \& Muysken (2004: 453), Záparo standard negation has double exponence.



The two negators are taykwá and -no. The first negator contains $k w a$, which we have already discussed. Like in Iquito the second negator is suffixal, but there is no connection with any andative meaning and perhaps it is not 'really' negative or not negative yet. At least in the later description by Moya (2007: 177), the suffix (spelled as $-n u$ ) is considered to be an infinitival suffix, an analysis endorsed by Lev Michael and Cynthia Hansen (p.c.).

$$
\text { Záparo (Moya 2007: 177) }
$$

8 There is a difference in spelling of taykwa between the two sources. Peeke (1962) spells it as taykwá, whereas Moya (2007: 174) suggests the spelling táykwa noting that it can be pronounced in a number of ways: [táykwá], [tákwá], and [táku]. In the examples we keep the spelling of the source. 


\section{Táykwa táwku ku páni-nu. NEG man I like-INF \\ 'I don't like the man.'}

The disagreement between the two grammarians could be indicative of an ongoing change affecting the infinitival suffix, in that they capture varieties reflecting a different stage in the development of the meaning of this element. In the variant studied by Peeke (1962) the suffix could be turning negative by its frequent co-occurrence with the standard negator. It is not originally negative, but is now being contaminated, just like argued for the Iquito prohibitive cuma and allowed as a possibility for Iquito -ji-. It is also possible that the Peeke's (1962) language variety shows contact interference. It is noted in Peeke (1962: 125) that her data come from three Záparo speakers, two of which were bilingual in Quichua. Quichua allows double negation (van der Auwera \& Vossen 2016: 197-201) and perhaps these speakers were influenced by Quechua ${ }^{9}$, with Záparo being in a state of attrition. Perhaps the speakers 'made a mistake'; but, as we recalled in the discussion of the Iquito single $-j i$ - pattern, native speakers are not linguists and how do languages change, if not through innovative uses or mistakes? Of course, Peeke's (1962) analysis could also be a descriptive error. In any case, the potential for a change from infinitive marker to negator is there, just like we have seen it for Iquito kuma.

The next thing we have to explain is why the older negator would combine with an infinitival suffix. The scenario we propose is that the structure with the negator followed by an infinitive was originally an existential structure. Applied to (16) this hypothesis puts 'there is no my liking of the man' as the original meaning. ${ }^{10}$ Potential support comes from the fact that the person marker, such as $k u / k o$ shown in (15-16) is also used in possessive (see Peeke 1962: 152). Although this feature is found in many South American languages, particularly Amazonian (cf. Dixon \& Aikhenvald 1999: 9), this could support the idea that the predicate was construed as a possessed element. ${ }^{11}$ Note that we are not claiming that (16) still means 'there is no my liking of the man'. That the existential meaning may well be disappearing is suggested by the fact that the verb does not have to take the $n u$ - suffix. In (17) the verb that combines with the taykwa negator takes an ordinary tense marker.

9 There is no information about the informants in Moya (2007). Clearly, Quichua could have its influence felt there as well.

10 Interestingly, under the lemma for French non 'no' Beuchat \& Rivet (1908: 244) list taykwa with the meaning il n'y pas 'there is no'.

11 This is also the case in Iquito (Hansen 2011: 28). A predicate-as-possessed-entity analysis would make most sense for the derivation verb stem used with $-j i$, but this form does not allow person prefixing, at least not in the negative use. 
(17) Záparo (Moya 2007: 177)

$\begin{array}{llll}\text { Táykwa ku páni-cha } & \text { tánahika. } \\ \text { NEG I I } & \text { want-PRS } & \text { honey }\end{array}$

'I don't want honey.'

This boils down to the hypothesis that taykwa is undergoing a Negative Existential Cycle (Croft 1991, Veselinova 2013, 2014, 2016, Veselinova \& Hamari (eds.) (Forthc.)). The ambivalent status of a taykwa is also shown when taykwa combines with a nominal. Taykwa can express existential negation by itself, but one can also add an existential verb in the - $n u$ form.

(18) Záparo (Moya 2007: 175)

$\begin{array}{lll}\text { Táykwa } & \text { (ikun-nu) }^{12} & \text { kwadirnu. } \\ \text { NEG } & \text { be-NEG } & \text { notebook }\end{array}$

'There is no notebook'

A further indication for the idea that taykwa may be losing its existential meaning is that there seem to be other and dedicated markers of existential negation, both combinable with taykwa,

(19) Záparo (Moya 2007: 175, 179, 176)

$\begin{array}{ll}\text { a. (Táykwa) áwnika chay ñaw. } \\ \text { NEG } & \text { tobacco NEG.EXI }\end{array}$

'There is no tobacco.'

$\begin{array}{lll}\text { b. (Táykwa) } & \text { kána ikwaka } & \text { áwnika } \\ \text { NEG } & \text { 1PL NEG.EXI } & \text { tobacco }\end{array}$

'We don't have tobacco.'

When taykwa is present, the examples in (19) show double exponence. About the (a)-case Moya (2007: 179) tells us that doubling produces emphasis. The ikwaka element in (b) is claimed to be from ikunu 'be' (Moya 2007: 176), but one could be tempted to assume it to contain kwa element as well.

We now come to the prohibitive and we see the two grammarians again do not agree. Peeke (1991: 41) reports the uses of a $-k w a$, preceded by various vowels, depending on vowel harmony.

(20) Záparo (Peeke 1991: 41)

$\begin{array}{lll}\text { Ča } & \text { atí- } i k w a & \text { kwi } \\ \text { 2SG } & \text { speak-PROH } & \text { 1sG.COM } \\ \text { 'Don't } & \text { speak to me.' } & \end{array}$

In Moya (2007), however, we find the $-k w a$ suffix together the particle

12 The version with ikunu is made up on the basis of examples with different lexical items found in Moya (2007: 175). 
taykwa and the $-k w a$ suffix is analysed as a kind of future or durative (Moya 2007: 202, 207).

(21) Záparo (Moya 2007: 178)
Táykwa cha ta
NEG 2SG $\quad$ húykwa.
'Don't play.'

It is possible that one of the two grammarians is simply mistaken. However, if we assume that both grammarians are at least partially right, the analysis we offered for the Iquito future suffix kuma and the Záparo infinitival suffix -no suggests that we could again be dealing with a contamination of a non-negative suffix with negative meaning.

To conclude about Záparo. The details are not clear, but there is a case for thinking that (i) both an infinitival and a tense aspect suffix are being reanalysed into a negator, a standard negator and a prohibitive one, thus once again, instantiating subtypes of a Jespersen Cycle, and (ii) that the existential negator may be undergoing a Negative Existential Cycle and thus becoming a standard negator.

\section{Arabela negation}

Arabela is not reported to have double negation, but there are two standard negation strategies.

Arabela (Rich 1999: 49, 60)
a. Maja
na
niishi-nu
NEG $\quad 3 \mathrm{SG}$
know-INF
'He doesn't know.'
b. Ua toji-yaqui-rii.
2SG listen-NEG-PRF
'You didn't listen.'

The first strategy has a negator followed by a verb in the infinitival form, as shown in (22a). We have had a strategy with an infinitival verb form in Záparo too and the two suffixes, i.e. -no/-nu in Záparo and -nu in Arabela, are no doubt related (de Carvalho 2013: 113). Rich (1999), like Moya (2007) but unlike Peeke (1962), does not see any reason for taking $-n u$ to be contaminated by the negator and thus form a doubling construction. The form maja is puzzling. The $m a$ formative has negative meaning in a large number of South American languages (David Payne 1990: 76; van der Auwera \& Krasnoukhova submitted). If it is negative, then maja ends up with two negative markers, for the ja part has negative meaning, too. We see the latter in the negator yaqui, which easily splits into a negative $y a$ and an existential qui (see below). Of course, we have 
to accept then that the two negators (i.e., $m a$ and $j a$ ) merge in a converbation, but this has been argued for other languages too, e.g. in Austronesian Lewo (Vossen 2016: 197, based on Early 1994a: 420, 1994b: 77) or in Bantu Kanincin (Devos, Kasombo Tshibanda \& van der Auwera 2010: 167). The fact that maja requires the infinitival ending (like in 22a) suggests that it has an existential origin. Like with Záparo taykwa the existential meaning may be bleaching: in (23) the negator maja is used in a clause where existence or, at least, location is expressed with a 'be/exist' verb.

\section{(23) Arabela (Rich 1999: 38)}

$\begin{array}{lllllll}\text { Quia } & \text { mueja } & \text { maja } & \text { kanaa } & \text { jiya-co } & \text { na } & \text { qui-niu. } \\ \text { 2SG } & \text { son } & \text { NEG } & \text { 1PL.EX } & \text { house-in } & 3 \text { SG } & \text { be-INF }\end{array}$

'Your son is not in our house.'

Note that the form of the existential verb in (23) is qui, the second component of the yaqui negation strategy shown in (22b). So it seems that, on the basis of the decomposability of yaqui into 'not' and 'exist', yaqui is in origin an existential construction. The presence of two strategies (as in 22) makes sense in the light of the Negative Existential Cycle. As soon as the former negative existential yaqui developed into a standard negation marker, a new negative existential strategy (with maja, in this case) emerged to fill in the void. Finally, yaqui has a counterpart in Iquito, viz. ajapaqui, illustrated in (14) (Lai 2009: 59; Hansen 2018: 141), but for Iquito the existential negator is not claimed to be developing a standard negator use.

For the prohibitive, Rich (1975: 10) reports the use of maja with an infinitival verb, but there is also a mysterious suffix $-t i(24)$.

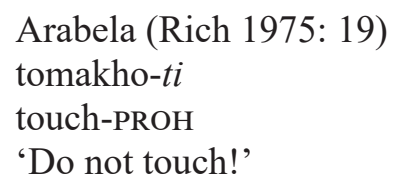

To conclude about Arabela: the documentation is sparse, but this much seems clear: there are two standard negators, one of which also takes care of prohibition, and they could both have a negative existential origin.

\section{Subclassifying Zaparoan}

We have presented tentative hypotheses on some aspects of negation in three Zaparoan languages. Let us now see how this particular element of grammar relates to the internal classification of Zaparoan. For the latter we first go back to Mason (1950). At that point of time, Mason (1950: 248) notes:

The classification of the component languages and dialects of the Záparoan family is in utter confusion; no attempt has ever been made 
to do this on a scientific linguistic basis, and the available data are insufficient. Most compilers have merely given a list of names of groups $[\ldots]$

This bleak judgment is repeated by McQuown (1955: 560) and today we often again just have lists (e.g. Fabre 1998: 1256; Adelaar 2004: 451; Hansen 2011: 3, 2018: 131; Wise 1999, 2005; Crevels 2012: 211). Similarly, though Michael, Beier \& Wauters (2011) have made headway in reconstructing ProtoZaparoan phonology, they claim they need more morphological work to dare to attempt an internal classification.

There are nevertheless three different subclassification proposals. In what follows we report these only with respect to the three languages studied in this paper. One is proposed by Kaufman (1994: 63), Fabre (2019), and Eberhard et al (eds.) (2010) (Ethnologue): Arabela is put together with Záparo.

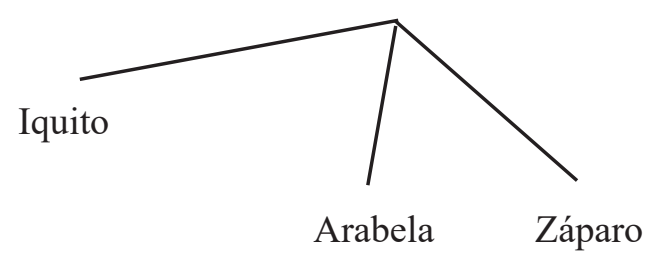

The second view is taken by De Carvalho (2013: 111), who worked on sound correspondences and cognates and this view is followed by Hammarström et al (2010) (Glottolog). Here Arabela is closer to Iquito.

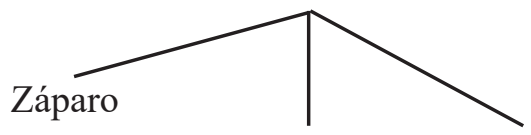

$$
\text { Arabela Iquito }
$$

The third view is adopted by Kaufman (2007: 69). It is arguably just a list again, but there could a difference. One can abstain from subgrouping because one lacks all knowledge - the 'pure' list approach, but also because there is knowledge but it does not show any subgroups (yet).

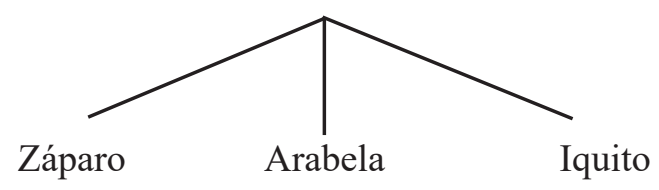

With respect to negation, the facts are clear. Arabela resembles Záparo more than Iquito and it thus aligns with the Kaufman - Ethnologue view in (25). Only in Arabela and Záparo do we see the workings of a Negative Existential Cycle 
and only in Iquito do we see a Jespersen Cycle variation between single, double, and triple exponence. Of course, negation is just one niche in the grammar of a language. It is perfectly possible that Arabela sometimes sides with Záparo and sometimes with Iquito, thus giving a constellation more like (27).

There are a few languages that are sometimes listed as possibly Zaparoan or close to Zaparoan, and one could look for similarities in their negation systems. The best case has probably been made for Yagua (yagu1244, Payne 1984, 1985; Kaufman 1994: 63). But, with respect to negation, Zaparoan and Yagua are different. Then there is Taushiro (taus1253, Peru) (Kaufman 1994: 63; Wise 2005: 51) but, again, the relevant negators are very different (Alicea Ortiz 1975: 107-110). Omurano (omur1241, Peru) is yet another potential Zaparoan language (Wise 1999: 308), but data on negation is lacking and the language is extinct by now. Intriguingly, there is a look-alike in the staunchly isolated language Urarina (urar1246), which uses a $k w a$ negator, more particularly in the prohibitive (28). Urarina is spoken in the Loreto province of Peru and thus in the 'wider vicinity' of Iquito (Olawsky 2006: 6) - though the phrase 'wider vicinity' 'is not meant to imply actual proximity' (Olawsky 2006: 6).

(28) Urarina (Olawsky 2006: 262)

kwa kurata-sa-1 ti-a

PROH two-times-PRT give-NTR

'Don't tell it twice.'

There is also a complex form kwatia used for emphasizing negation and thereby manifesting double exponence, with, in some cases (as in (29)), a negative $-j i$.

(29) Urarina (Olawsky 2006: 263)

[...] kwatia kauatça-ri- $j i=$ ta

NEG good-IRR-NEG.3SGA=FRS

'[...] it would not be good'

Intriguingly again, the -tia bit of kwatia also resembles an old Yagua negator -ta or -tya ('occasionally -vitya', Payne 1985b: 88).

\section{Conclusion}

In this paper we revisited negation, primarily standard negation, in the three Zaparoan languages Iquito, Záparo and Arabela. On a purely descriptive level, we relied on the extant studies, assuming that they are basically correct, and we have also considered the differences found in the synchronic analyses of the languages in question. We suggested that a difference can be interpreted from a diachronic perspective. For Iquito, which exhibits single, double as well as triple 
negation, we applied a Jespersen Cycle perspective and found it to be useful. For Záparo and Arabela another Cycle hypothesis proved enlightening, i.e., the Negative Existential Cycle. We also speculated that both in Iquito and Záparo there is a diachronic link between the formal expression of negation and of the concept for leaving/going. Finally, we addressed the internal subclassification of the Zaparoan languages, showing that, at least for the structural feature of negation, the position of Arabela is closer to Záparo than to Iquito.

\section{Abbreviations}

1 first person

2 second person

IRR irrealis

3 third person

M masculine

A subject of transitive clause

MMT momentary

COM complement

NEG negation

DET determiner

NPST non-past

EXI existential

NTR neutral

EC extended current (tense)

PL plural

EMPH emphasis

Poss possessive

EX exclusive

POT potential

FRS frustrative

PREV preventive

FUT future

GEN general (number)

PRF perfective

GNR general (aspect)

PROH prohibitive

IMPF imperfective

PRS present

INCP Inceptive

INF infinitive

PRT participle

SG singular

$\mathrm{v}$ verb

\section{References}

Adelaar, Willem F. \& Pieter C. Muysken. 2004. The languages of the Andes. Cambridge: Cambridge University Press.

Alicea Ortiz, Neftalí. 1975. Analisis preliminar de la gramatica del idioma Taushiro. Lima: Instituto Lingüistico de Verano.

Beier, Christine, Brenda Bowser \& Vivian Wauters. 2014. Diccionario Záparo Trilingue: Sápara-Castellano-Kichwa / Castellano-Sápara y Kichwa-Sápara. Quito: Abya-Yala.

Beier, Christoine \& Lev Michael. 2018. Language revalorization in Peruvian Amazonia, through the lens of Iquito, Leanne Hinton, Leena Marjata Huss \& Gerald Roche (eds.) The Routledge Handbook of Language Revitalization, Abingdon : Routledge, 406-414. 
Beuchat. H. \& P. Rivet. 1908. La famille linguistique zaparo. Journal de la Société des Américanistes de Paris 5: 235-249.

Birchall, Joshua. 2014. The multi-verb benefactive construction in Wari' and Oro Win, Francesc Queixalós, Stella Telles \& Ana Carla Bruno (eds.) Incremento de Valencia en las Lenguas Amazónicas. Bogotá: Instituto Caro y Cuervo, 111-132.

Campbell, Lyle. 2012. Classification of the indigenous langauges of South America, Campbell \& Grondona (eds.), 59-166.

Campbell, Lyle \& Verónica Grondona (eds.) The indigenous languages of South America: A comprehensive guide. Berlin: De Gruyter.

Crevels, Mily. 2012. Language endangerment in South America: The clock is ticking. Campbell \& Grondona (eds.), 166-233.

Croft, William. 1991. The evolution of negation. Journal of Linguistics 27: 1-27.

de Carvalho, Fernando O. 2013. On Záparoan as a valid genetic unity: Preliminary correspondences and the status of Omurano. Revista Brasileira de Linguística Antropológica 5: 91-116.

Devos, Maud, Michael Kasombo Tshibanda \& Johan van der Auwera. 2010. Jespersen cycles in Kanincin: double, triple and maybe even quadruple negation, Africana Linguistica 16: 155-182.

Dixon, R.M.W. \& Alexandra Aikhenvald 1999. Introduction. R.M.W. Dixon \& Alexandra Aikhenvald (eds.) The Amazonian Languages. Cambridge: Cambridge University Press, 1-22.

Dryer, Matthew S. 2013. 'Order of Negative Morpheme and Verb', Matthew S. Dryer \& Martin Haspelmath (eds.), The World Atlas of Language Structures Online. Leipzig: Max Planck Institute for Evolutionary Anthropology http://wals.info/chapter/143, accessed on 11 July 2019.

Early, Robert. 1994a. A grammar of Lewo, Vanuatu. Doctoral dissertation Australian National University.

Early, Robert. 199b. Lewo. Peter Kahrel \& René van der Berg (eds.) Typological studies in negation. Amsterdam: Benjamins, 65-93.

Eastman, Elizabeth \& Eastman, Robert. 1963. Iquito syntax. Benjamin F. Elson (ed.), Studies in Peruvian Indian Languages 1, 145-192. Norman: Summer Institute of Linguistics.

Eberhard, David M., Gary F. Simons, and Charles D. Fennig (eds.). 2019. Ethnologue: Languages of the World. Twenty-second edition. Dallas, Texas: SIL International. (Available online at http://www.ethnologue.com, Accessed on 2019-08-13).

Epps, Patience, John Huehnergard \& Na'ama Pat-El. 2013. Introduction: Contact among genetically related languages. [Special issue]. Journal of Language Contact 6(2): 209-219.

Fabre, Alain. 1998. Manual de las lenguas indígenas sudamericanas. München: LINCOM Europa. 
Fabre, Alain. 2019. Diccionario Etnolingüístico y Guía Bibliográfica de los Pueblos Indígenas Sudamericanos. Www.ling.fi/Entradas\%20diccionario/ Dic=Zaparo.pdf $<$ accessed on July 11 2019>

Gast, Volker \& Johan van der Auwera. 2012. What is 'contact-induced grammaticalization'? Examples from Mayan and Mixe-Zoquean languages. Björn Wiemer, Bernhard Wälchli \& Björn Hansen (eds.) Grammatical replication and borrowability in language contact. Berlin: De Gruyter Mouton, 381-425.

Givón, Talmy. 1971. Historical syntax and synchronic morphology: an archaeologist's field trip. Chicago Linguistic Society 7: 394-415.

Hammarström, Harald, Robert Forkel \& Martin Haspelmath. 2019. Glottolog 4.0. Jena: Max Planck Institute for the Science of Human History. (Available online at http:// glottolog.org, Accessed on 2019-08-28.)

Hansen, Cynthia 2011. Expressing reality status through word order: Iquito irrealis constructions in typological perspective. PhD Dissertation, University of Texas at Austin.

Hansen, Cynthia. 2018. Subordinate and interrogative clause negation in Iquito. Linguistic Typology 22(1): 119-163.

Heine, Bernd \& Tania Kuteva. 2002. World lexicon of grammaticalization. Cambridge: Cambridge University Press.

Heine, Bernd \& Tania Kuteva. 2003. On contact-induced grammaticalization. Studies in Language 27(3): 529-572.

Hober, Nicole. 2019. The grammaticalization of motion verbs in the languages of the Americas and Austronesia: Beyond the encoding of motion. Paper presented at Paper presented at the Annual Meeting of the Societas Linguistica Europaea (SLE), Leipzig, 21-24 August 2019.

Horn, Laurence R. 1989. A natural history of negation. Chicago: The University of Chicago Press.

Kaufman, Terrence, with the help of Brent Berlin. 1994. The native languages of South America. Christopher Moseley \& R. E. Asher (eds.), Atlas of the world's languages. London: Routledge, 46-72.

Kaufman, Terrence, with the help of Brent Berlin. 2007. South America. R. E. Asher $\&$ Christopher Moseley (eds.), Atlas of the world's languages. $2^{\text {nd }}$ ed. London: Routledge, 61-93.

Krasnoukhova, Olga \& Johan van der Auwera. 2019. Standard negation in Awa Pit: From synchrony to diachrony. Folia Linguistica Historica 40(2): 439-474.

Kuteva, Tania, Bernd Heine, Bo Hong, Haiping Long, Heiko Narrog \& Seongha Rhee. 2019. Word Lexicon of Grammaticalization, Cambridge: Cambridge University Press.

Lai, I-Wen. 2009. Time in the Iquito Language. PhD Dissertation, University of Texas at Austin. 
Marchese, Lynell. 1986. Tense/aspect and the development of auxiliaries in Kru languages. Arlington, Texas: Summer Institute of Linguistics.

Mason, J. Alden. 1950. 'The languages of South American Indians. Julian H. Steward (ed.) Physical anthropology, linguistics and cultural geography of South American Indians. Vol 6. Washington: Smithsonian Institution, 159-317.

McQuown, Norman A. 1955. The indigenous languages of South America. American Anthropologist 57: 501-570.

Miestamo, Matti. 2005. Standard negation. The negation of declarative verbal main clauses in a typological perspective. Berlin: Mouton de Gruyter.

Moya, Ruth. 2007. Esbozo gramatical de la lengua sápara. Quito: UNESCO.

Moya, Ruth. 2009. Pana sápara atupama, Nuestra lengua sápara: Diccionario trilingüe Sápara-Castellano-Quichua. Ecuador: Ministerio de Educación.

Olawsky, Knut J. 2006. A Grammar of Urarina. Berlin, New York: Mouton de Gruyter.

Pakendorf, Brigitte \& Ewa Schalley. 2007. From possibility to prohibition: A rare grammaticalization pathway. Linguistic Typology 11: 515-540.

Pauwels, J.L. 1958. Het dialect van Aarschot en omstreken. Brussel: Belgisch interuniversitaire centrum voor Neerlandistiek.

Payne, Doris L. 1984. Evidence for a Yaguan-Zaparoan connection. Work Papers of the Summer Institute of Linguistics, University of North Dakota Session 28: 131-156.

Payne, Doris L. 1985a. Aspects of the grammar of Yagua: a typological approach. Doctoral dissertation, University of California at Los Angeles.

Payne, Doris L. 1985b. -ta in Zaparoan and Peba-Yaguan. International Journal of American Linguistics 51: 529-531.

Payne, David L. 1990. Some widespread grammatical forms In South American Languages. Doris L. Payne (ed.) Amazonian Linguistics. Studies in Lowland South American languages. Austin: University of Texas Press, 75-87.

Peeke, Catherine. 1954. Shimigae, idioma que se extingue. Peru Indígena 5: 171-178.

Peeke, Catherine.1962. Structural summary of Záparo. Benjamin F. Elson (ed.), Studies in Ecuadorian Indian languages 1, 125-216. Norman, Oklahoma: Summer Institute of Linguistics of the University of Oklahoma.

Peeke, Catherine (revised by Mary Ruth Wise \& Stephen Levinsohn). 1991. Bosquejo grammatical del zaparo. (Cuadernos Ethno-Lingüísticos 14). Quito: Instituto Lingüístico de Verano

Rich, Rolland. 1975. Sufijos verbales y apuntes gramaticales sobre el idioma arabela. (Datos Etno-Lingüísticos 18) Lima: Instituto Lingüístico de Verano.

Rich, Rolland. 1999. Diccionario Arabela-Castellano. Lima: Instituto Lingüístico de Verano.

Salaberri, Iker. 2017. Subordination and syntactic change: A cross-linguistic study. Ms. van der Auwera, Johan. 2009. The Jespersen cycles. Elly van Gelderen (ed.) Cyclical change. Amsterdam: Benjamins, 35-72. 
van der Auwera, Johan. 2010. On the diachrony of negation. Laurence R. Horn (ed.) The expression of negation. Berlin: De Gruyter Mouton, 73-109.

van der Auwera, Johan, Nina Dobrushina \& Valentin Goussev. 2003. A Semantic Map for Imperative-Hortatives. Dominique Willems, Bart Defrancq, Timothy Colleman \& Dirk Noël (eds.), Contrastive Analysis in Language. Identifying Linguistic Units of Comparison.Basingstoke: Palgrave Macmillan, 44-66.

van der Auwera, Johan \& Olga Krasnoukhova. Forthc. The typology of negation. Viviane Déprez \& M. Teresa Espinal (eds.), The Oxford handbook of negation. Oxford: Oxford University Press.

van der Auwera, Johan \& Olga Krasnoukhova. Subm. Negative ma in South America with a focus on its standard negative postverbal $m a$ in Panoan, Takanan and Tukanoan. In Mily Crevels, Hein van der Voort \& Matti Miestamo (eds.) Negation in Amazonian Languages. [Studies in Diversity Linguistics series]. Berlin: Language Science Press.

van der Auwera, Johan, Olga Krasnoukhova \& Frens Vossen. Forthc. Intertwining the negative cycles. Veselinova \& Hamari (eds.)

van der Auwera, Johan \& Frens Vossen. 2016. Jespersen cycles in the Mayan, Quechuan and Maipurean languages. In Elly van Gelderen (ed.), 189-218.

Van de Velde, Freek \& Muriel Norde. 2016. Exaptation. Taking stock of a controversial notion in linguistics', Muriel Norde \& Freek Van de Velde (eds.). Exaptation and language change. Amsterdam: Benjamins, 1-35.

Van Gelderen, Elly (ed.) Cyclical change continued. Amsterdam: Benjamins.

Veselinova, Ljuba 2013. Negative existentials: a cross-linguistic study, Italian Journal of Linguistics 25: 107-145.

Veselinova, Ljuba 2014. The negative existential cycle revisited', Linguistics 52: 1327 1389.

Veselinova, Ljuba. 2016. The negative existential cycle viewed through the lens of comparative data. van Gelderen (ed.), 139-187.

Veselinova, Ljuba \& Arja Hamari (eds.) Forthc. The Negative Existential Cycle from a historical-comparative perspective. Language Science Press.

Vossen, Frens. 2016. On the typology of the Jespersen cycles. Doctoral dissertation University of Antwerp.

Weir, E.M. Helen. 1984. A negação e outros tópicos da gramática Nadëb, Master thesis Universidade Federal de Campinas.

Wise, Mary Ruth. 1999. Small language families and isolates in Peru. R.M.W. Dixon \& Alexandra Y. Aikhenvald (eds.) The Amazonian languages. Cambridge: Cambridge University Press, 306-340.

Wise, Mary Ruth. 2005. Apuntes sobre las lenguas Záparos - familia que se extingue. Revista Latinoamericana de Estudios Etnolinguísticos 11: 51-69. 